$1-1-1956$

\title{
The number of bacteria, fungi, and actinomycetes in some strip-mine spoil
}

\author{
H. A. Wilson
}

Gwendolyn Stewart

Follow this and additional works at: https://researchrepository.wvu.edu/ wv_agricultural_and_forestry_experiment_station_bulletins

\section{Digital Commons Citation}

Wilson, H. A. and Stewart, Gwendolyn, "The number of bacteria, fungi, and actinomycetes in some strip-mine spoil" (1956). West Virginia Agricultural and Forestry Experiment Station Bulletins. 388T.

https://researchrepository.wvu.edu/wv_agricultural_and_forestry_experiment_station_bulletins/638 @ WVU. It has been accepted for inclusion in West Virginia Agricultural and Forestry Experiment Station Bulletins by an authorized administrator of The Research Repository @ WVU. For more information, please contact ian.harmon@mail.wvu.edu. 
West Virginia University Libraries

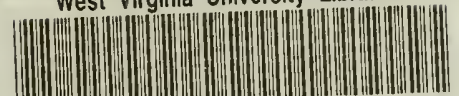

308021008961280

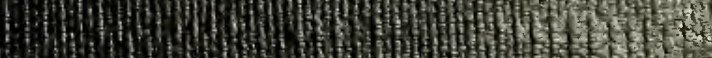

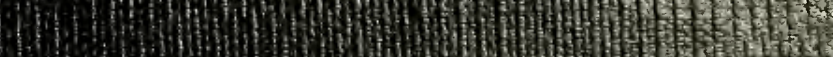
2in 4 ,

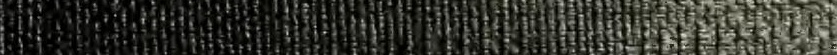

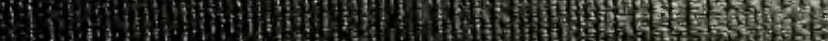

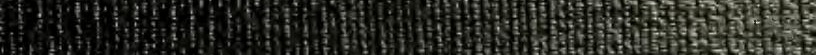

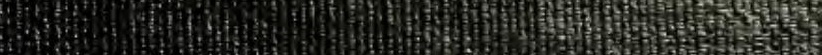
6.6 .

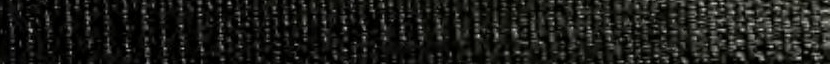
1.

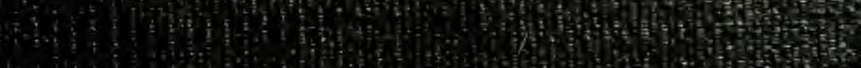
tis

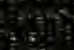


Digitized by the Internet Archive in 2010 with funding from Lyrasis Members and Sloan Foundation 
February 1956

The Number of Bacteria, Fungi, and Actinomycetes In Some Strip-Mine Spoil 


\title{
THE AUTHORS
}

Harold A. Wilson is Associate Bacteriologist at the West Virginia University Agricultural Experiment Station and Associate Professor of Bacteriology in the College of Agriculture, Forestry, and Home Economics. Gwendolyn Stewart was Assistant in Bacteriology at the West Virginia University Agricultural Experiment Station.

\author{
WEST VIRGINIA UNIVERSITY \\ Agricultural EXPERIMENT Station \\ College of Agriculture, Forestry, and Home Economics \\ H. R. VARNEY, DIRECTOR \\ MORGANTOWN
}




\section{Summary}

The numbers of bacteria, fungi, and actinomycetes were determined in the 0-4-inch and 4-8-inch layers in the spoil of coal strip-mining operations from nonvegetated, vegetated, and adjacent undisturbed soil in West Virginia.

The numbers of bacteria, fungi, and actinomycetes were in most cases significantly greater in the vegetated spoil than in nonvegetated spoil. In general, the numbers of microorganisms were larger in the 4-8-inch layer of nonvegetated spoil than in the 0-4-inch layer. In vegetated spoil, whether revegetated with forage grasses and legumes, pine or black locust, the 0 -4-inch layer usually contained more microorganisms than the 4-8-inch layer.

Spoil supporting vegetation usually contained numbers of bacteria, fungi, and actinomycetes which approached, and in a few cases were larger, than those of adjacent soil areas which had not been disturbed by the stripping operations.

The numbers of certain physiological groups of bacteria, the ammonifiers, denitrifiers, nitrifiers, cellulose-decomposers, sulfur-oxidizers and Azotobacter, were determined in the 0-5-inch depth of the Canyon and Arthurdale strip-mined areas.

No Azotobacter were found in any of the samples, even though one spoil and one soil sample had a $\mathrm{pH}$ of 6.0 or above. The nitrifying bacteria were not present in the Canyon nonvegetated and vegetated and the Arthurdale nonvegetated samples.

The numbers of ammonifiers, denitrifiers, and cellulose-decomposers were much larger in spoil with vegetation, and particularly with vegetation and surface litter, than in the nonvegetated spoil.

The numbers of sulfur-oxidizers determined in this study exhibited no over-all definite trend, although in the Canyon area their numbers decreased as the $\mathrm{H}$-ion concentration decreased.

Twenty-two genera of fungi were identified, nine of which were found only in the spoil and three only in the soil. 



\section{The Number of Bacteria, Fungi, and Actinomycetes In Some Strip-Mine Spoil}

H. A. WILSON and GWENDOLYN STEWART

N strip mining the overburden of soil and rock above a coal seam is dumped to one side where it forms spoil banks consisting of a mixture of broken rocks, shales, clays, coal fragments, sometimes pyrites, and the original soil. Some spoils are acid, and others approach neutrality.

In West Virginia (14) spoil was originally classified into three general types based on the prevailing hydrogen-ion concentration of the spoil surface. Spoils of Class I are strongly acid, having a $\mathrm{pH}$ of less than 5.5. Class II spoils, with a $\mathrm{pH}$ range of from 5.5 to 6.5 are termed slightly acid. Class III consists of neutral and limy soils with a $\mathrm{pH}$ of above 6.5 .

Although the acidity of spoil areas may result in part from the bacterial oxidation of pyritic materials $(2,4)$ associated with certain coal seams, the microbiology of strip-mine spoil in general has been neglected (15). Most investigations of spoil have been concerned chiefly with means of revegetating spoil banks with forage grasses and legumes or with their reforestation.

The purposes of the work reported here were to determine the "total" numbers of bacteria, fungi, and actinomycetes in spoil, with and without vegetative cover, and to compare these numbers with those in near-by undisturbed soil; and to obtain an estimation of the various physiological groups of bacteria present in spoil and to compare these with the physiological groups in an undisturbed soil nearby.

\section{Materials and Methods}

Four strip-mined areas in West Virginia were included in this study. Within each of these, samples could be obtained from both spoil devoid of vegetation and from vegetated spoil. Samples of undisturbed and apparently unmodified soil could be obtained nearby. Following is a brief description of the areas:

CANYON: Located in Monongalia County and strip mined in 1943. Following the stripping operations, the spoil was leveled and a portion was limed, fertilized, and seeded to forage grasses and legumes by Tyner and associates $(11,12)$. 
Pruntytown: Coal removal from this Taylor County area was completed in 1946, and the spoil was leveled in 1947. In 1948 part of the area was fertilized and seeded to soybeans. The next year wheat was sown as a nurse crop for grass and clover seed.

ARTHURDALE: Stripping operations probably took place on this Preston County area in 1943-44. In 1944 one portion was limed, fertilized, and seeded to forage plants by Tyner, et al (12). Other portions were planted to pine (Pinus sp.) and to black locust (Robinia pseudoacacia L.) by the Division of Forestry, West Virginia University, in 1945. Neither lime nor fertilizer was applied to the reforested portions.

Kaufmann: The leveling of this small area in Marion County was finished in 1947, after which it was seeded to lespedeza (Lespedeza stipulacea Maxim). It is not known whether this area was ever limed or fertilized.

Spoils have no profile development, so samples for total counts were taken arbitrarily at depths of $0-4$ inches and $4-8$ inches. Total counts of bacteria, fungi, and actinomycetes were made on composite samples, each of which consisted of three smaller samples taken at random within a given portion of an area and thoroughly mixed. Total counts were made for two such samples from each section.

It is recognized that storage of soil samples, even under refrigeration, for a few hours may lead to quantitative changes in the soil flora, and that these changes may not be equal for different groups of microorganisms. Consequently, all samples were immediately sieved at site of collection in order to remove the rocks, coal, and such materials usually associated with spoil. The samples were then brought to the laboratory and plated the same day.

The numbers of bacteria, fungi, and actinomycetes were determined by the usual dilution and plating techniques. Five plates were made from each dilution. The plating medium for bacteria was sodium caseinate agar and for the actinomycetes a glycerol agar (5). Rose bengal agar (9) was used for plating the fungi. The original soil:water dilution (1:10) was shaken for five minutes and subsequent dilutions for three minutes before plating. All shaking was done on a Precision equipoise shaker.

The bacteria were usually counted after 5 days incubation; the fungi after 3 days; and the actinomycetes after 10 days. Occasionally, the plates were retained for somewhat longer periods than indicated and recounted. These longer incubation times failed to change the total counts. Incubation was at $25^{\circ} \pm 1^{\circ} \mathrm{C}$.

The procedure followed for collecting the samples used in estimating the most probable number (MPN) of bacteria of the physiological groups 
was essentially the same as that for total counts with the exception that samples were obtained from only one depth (0-5 inches). Suitable serial dilutions were prepared from the duplicate samples, and five tubes were inoculated from each dilution. Incubation was at $25^{\circ} \pm 1^{\circ} \mathrm{C}$. The results are given as the MPN of organisms per gram of spoil on an oven-dry basis.

Numbers of ammonifying bacteria were estimated using Kappen's urea broth (8) after 5 days incubation on the basis of odor and $\mathrm{pH}$ change. Numbers of denitrifying bacteria were estimated in aspargine nitrate broth (5). Tests were made for the presence of ammonium, nitrites and nitrates after incubation for 14 days. The MPN of nitrifying bacteria was determined on Winogradsky's ammonium sulfate medium (5). After incubation for 30 days, tests were made for ammonium and nitrites. Cellulose decomposing bacteria were estimated by inoculating an ammonium sulfate-cellulose solution (5) and examining after incubation for 30 days. Sulfur-oxidizing bacteria were estimated after 30 days incubation in medium I (13) on the basis of turbidity and pH. Azotobacter determinations were made on the surface of a benzoate-containing medium (1) sprinkled with soil or spoil.

Samples from the different parts of each spoil area are designated as follows: "nonvegetated" refers to samples from the bare spoil; "vegetated" to those from spoil supporting any type of vegetation, except trees; "pine" to the samples from that portion of the Arthurdale spoil planted to pines; "locust" to samples from the portion of the same area planted to black locust; and "undisturbed" refers to the samples from nonstripped soil located adjacent to the stripped areas and not directly influenced by the stripping operations.

The "total" counts obtained were analyzed by the analysis of variance.*

\section{Results}

The data obtained in these studies on the total counts of bacteria, fungi, and actinomycetes in strip-mine spoils are presented in Tables 1 and 2. In Table 1 the total counts are given in actual numbers. In Table 2 the same data are presented as logarithmic means upon which the analysis of variance was determined. Also given in this table are the $\mathrm{LSD}_{05}$ values for treatments and depths wherever significant differences were found.

\section{BACTERIA}

Less bacteria per gram of spoil were found in the nonvegetated spoils at both depths than in the corresponding depths of the vegetated *The authors wish to thank Dr. W. D. Foster, cormerly with the West Virginia University
Agricultural Experiment Station, for his assistance with the analysis of variance. 
Table 1. Numbers (in Thousands) of Bacteria, Fungi, and Actinomycetes Per Gram of Strip-Mine Spoil (Oven-Dry Basis)

\begin{tabular}{|c|c|c|c|c|c|c|c|c|}
\hline \multirow{3}{*}{$\begin{array}{c}\text { SPOIL AREAS } \\
\text { AND TYPE }\end{array}$} & \multicolumn{6}{|c|}{ MiCroorgaNisM } & \multirow{2}{*}{\multicolumn{2}{|c|}{$\begin{array}{c}\text { SOIL ACIDITY } \\
(\mathrm{pH})\end{array}$}} \\
\hline & \multicolumn{2}{|c|}{ BACTERIA } & \multicolumn{2}{|c|}{ FUNGI } & \multicolumn{2}{|c|}{ ACTINOMYCETES } & & \\
\hline & $0-4 *$ & $t-8$ & $0-4$ & $4-8$ & $0-4$ & $4-8$ & $u-4$ & $4-8$ \\
\hline CANYON & & & & & & & & \\
\hline Nonvegetated & i & 26 & 8 & 10 & 1 & 5 & 3.28 & 3.40 \\
\hline Vegetated ....... & 1135 & 141 & 280 & 35 & 181 & 23 & 3.88 & 3.35 \\
\hline Undisturbed ... & 1354 & 805 & 49 & 23 & 1980 & 444 & 4.70 & 4.88 \\
\hline PRUNTYTOWN & & & & & & & & \\
\hline Nonvegetated & 101 & 61 & 37 & 30 & 19 & 38 & 4.02 & 4.82 \\
\hline Vegetated ....... & 3050 & 111 & 360 & 26 & 220 & 154 & 3.78 & 3.14 \\
\hline Undisturbed & 4630 & 1920 & 395 & 59 & 4360 & 3270 & 6.52 & 6.78 \\
\hline KAUFMANN & & & & & & & & \\
\hline Nonvegetated & 12 & 38 & 133 & 29 & 140 & 9 & 3.46 & 3.70 \\
\hline Vegetated ....... & 21120 & 2274 & 181 & 39 & 4500 & 21360 & 6.95 & 7.00 \\
\hline Undisturbed & 5250 & 2220 & 252 & 56 & 2260 & 1130 & 5.22 & 4.98 \\
\hline ARTHURDALE & & & & & & & & \\
\hline Nonvegetated & 41 & 41 & 17 & 17 & 6 & 8 & 3.75 & 3.75 \\
\hline Vegetated ........ & 5840 & 3390 & 51 & 32 & 2410 & 367 & 6.00 & 5.30 \\
\hline Pines ……............ & 583 & 281 & 79 & 25 & 274 & 121 & 4.72 & 4.62 \\
\hline Locust & 1120 & 357 & 62 & 3 & 147 & 18 & 4.49 & 4.52 \\
\hline Undisturbed ... & 11210 & 1296 & 213 & 32 & 2420 & 1520 & 5.30 & 5.70 \\
\hline
\end{tabular}

*Depth in inches.

Table 2. Logarithmic Means of Numbers (in Thousands) of Bacteria, Fungi, and Actinomycetes in STRIP-Mine Spoll

\begin{tabular}{|c|c|c|c|c|c|c|}
\hline \multirow{3}{*}{$\begin{array}{l}\text { SPOIL AREAS } \\
\text { AND TYPE }\end{array}$} & \multicolumn{6}{|c|}{ MICROORGANISM } \\
\hline & \multicolumn{2}{|c|}{ BACTERIA } & \multicolumn{2}{|c|}{ FUngI } & \multicolumn{2}{|c|}{ ACTINOMYCETES } \\
\hline & $0-4^{*}$ & $4-8$ & $0-4$ & $4-8$ & $0-4$ & $4-8$ \\
\hline \multicolumn{7}{|l|}{ CANYON } \\
\hline Nonvegetated & 3.78 & 4.41 & 3.90 & 4.00 & 3.00 & 3.70 \\
\hline Vegetated & 6.06 & 5.15 & 5.45 & 4.54 & 5.26 & 4.36 \\
\hline Undisturbed & 6.12 & 5.90 & 5.69 & +.36 & 6.30 & 5.65 \\
\hline $\begin{array}{l}\text { Treatments L.S.D. } \\
\text { Depths L.S.D. }\end{array}$ & \multicolumn{2}{|c|}{1.90} & \multicolumn{2}{|c|}{1.30} & \multicolumn{2}{|c|}{1.14} \\
\hline \multicolumn{7}{|l|}{ PRUNTYTOWN } \\
\hline Nonvegetated & 5.00 & 4.79 & 4.57 & 4.48 & 4.28 & 4.58 \\
\hline Vegetated & 6.48 & 5.05 & 5.56 & 4.41 & 5.34 & 5.19 \\
\hline Undisturbed ...................... & 6.67 & 6.28 & 5.66 & 4.77 & 6.64 & 6.51 \\
\hline Treatments L.S.D.05 & \multirow{2}{*}{\multicolumn{2}{|c|}{$\begin{array}{r}.89 \\
1.27\end{array}$}} & \multicolumn{2}{|c|}{$\begin{array}{r}.72 \\
1.01\end{array}$} & \multirow{2}{*}{\multicolumn{2}{|c|}{1.01}} \\
\hline Depths L.S.D.05 .... & & & & & & \\
\hline \multicolumn{7}{|l|}{ KAUFMANN } \\
\hline Nonvegetated ...... & 4.08 & 4.58 & 5.12 & 4.46 & 5.15 & 3.93 \\
\hline Vegetated & 7.32 & 6.36 & 5.26 & 4.59 & 6.65 & 7.33 \\
\hline Undisturbed & 6.72 & 6.35 & 5.40 & 4.75 & e.35 & 6.05 \\
\hline Treatments L.S.D. & \multirow{2}{*}{\multicolumn{2}{|c|}{1.37}} & \multirow{2}{*}{\multicolumn{2}{|c|}{$\overline{.48}$}} & \multirow{2}{*}{\multicolumn{2}{|c|}{1.39}} \\
\hline Depths L.S.D.0. .... & & & & & & \\
\hline \multicolumn{7}{|l|}{ ARTHURDALE } \\
\hline Nonvegetated & 4.61 & 4.61 & 4.23 & 4.23 & 3.78 & 3.90 \\
\hline Vegetated ......................... & 6.77 & 6.53 & 4.71 & 4.51 & 6.38 & 5.56 \\
\hline Pine ……......................... & 5.77 & 5.45 & 4.90 & 4.40 & 5.44 & 5.08 \\
\hline Locust & 6.05 & 5.55 & 4.79 & 3.48 & 5.17 & 4.26 \\
\hline Undisturbed ....................... & 7.05 & 6.11 & 5.33 & 4.51 & 6.38 & 6.18 \\
\hline Treatments L.S.D.05 & \multirow{2}{*}{\multicolumn{2}{|c|}{.95}} & \multirow{2}{*}{\multicolumn{2}{|c|}{$\begin{array}{l}.20 \\
.29\end{array}$}} & \multirow{2}{*}{\multicolumn{2}{|c|}{$\begin{array}{l}.49 \\
.69\end{array}$}} \\
\hline Depths L.S.D.0s ..... & & & & & & \\
\hline
\end{tabular}

*Depth in inches. 
spoil on all areas. Differences were quite large, particularly in the 0-4inch depth.

The bacterial numbers in nonvegetated areas at 0-4 depth ranged from a low of 6 thousand per gram in the Canyon spoil to a high of 101 thousand in the Pruntytown spoil. The numbers in the vegetated spoils at the 0-4-inch depth ranged from 1,135 thousand in the Canyon area to 21,120 thousand in the Kaufmann area.

In samples of nonvegetated spoil from the 4-8-inch depth the numbers of bacteria were lowest in the Canyon and Kaufmann areas and highest in the Pruntytown area; 26 thousand, 28 thousand, and 61 thousand bacteria per gram of spoil respectively. The minimum number found in vegetated spoil at 4-8-inch depth was 111 thousand for the Pruntytown area, and the maximum was 3,390 thousand for the Arthurdale area.

The numbers of bacteria in the pine and locust spoils of the Arthurdale area, though considerably larger than those found in nonvegetated spoil, are much smaller than the numbers found in the vegetated spoil and the undisturbed soil in this area.

In no instance did the numbers of bacteria in the nonvegetated spoil closely approach those in the undisturbed soil from the same area. The numbers in vegetated spoil sometimes approached those in the undisturbed soil from the same area and in other instances approximated the numbers obtained for corresponding nonvegetated spoil.

Some statistically significant differences were found between the numbers of bacteria in nonvegetated, vegetated, and undisturbed samples in all spoil areas. Significant differences between depths were found only in the Pruntytown areas (Table 2).

\section{FUNGI}

The numbers of fungi in all the vegetated spoil samples, at both depths, are larger than those in the nonvegetated spoil, except in the 4-8-inch depth of the Pruntytown area. Less than 50 thousand fungus colonies per gram developed from all nonvegetated spoil samples except for the Kaufmann area in the $0-4$-inch depth. All the vegetated spoils contained more than 50 thousand per gram in the 0 -4-inch layer and less than that in the 4-8-inch layer.

The pine spoil of the Arthurdale area contained more fungi at both depths than the locust spoil, whereas more bacteria were found in the latter. The numbers of fungi in these reforested spoils in the 0-4-inch depth were about the same as in the vegetated spoil and much smaller than that of the undisturbed soil of the area. On the other hand, the 4-8-inch depth of the vegetated, pine, and undisturbed spoil were nearly 
equal, but that of the locust spoil was even smaller than the number in nonvegetated spoil.

The differences associated with treatments between the numbers of fungi in the various types of spoil are significant except in the Kaufmann area. Differences associated with depth are significant in all except the Canyon area.

\section{ACTINOMYCETES}

The vegetated spoil of all areas, at both depths, contained more actinomycetes than did the nonvegetated spoil. Except for the extremely large number of actinomycetes (2,360 thousand) found in the Kaufmann vegetated 4-8-inch depth, more actinomycetes were found in the 0-4-inch than in the 4-8-inch layer. The numbers ranged from 1 thousand to 140 thousand in the $0-4$-inch depth, and from 5 thousand to 367 thousand in the 4-8-inch depth in the nonvegetated spoils. Comparable numbers for the vegetated spoils were 181 thousand to 4,500 thousand and 23 thousand to more than 21,000 thousand. The latter number is larger than usually found for actinomycetes and can be attributed either to an error in sampling or laboratory technique.

Like the fungi, larger numbers of actinomycetes were found in both layers of the Arthurdale pine spoil than in the locust portion of the area.

The undisturbed soils, except that of the Kaufmann area, contained more actinomycetes than the corresponding spoils.

The differences associated with treatments in numbers of actinomycetes in the various spoil and soil samples were significant in all areas. The only significant difference associated with depth in number of actinomycetes was in the Arthurdale area.

\section{PHYSIOLOGICAL GROUPS}

Two spoil areas, Canyon and Arthurdale, were selected to determine the MPN of certain physiological groups of bacteria. These areas were chosen because of their availability, known history, and the pine and black locust plantings in the Arthurdale area. The physiological groups determined were the ammonifiers, nitrifiers, denitrifiers, cellulose-decomposers, sulfur-oxidizers, and Azotobacter. In addition, platings into rose bengal agar were made from the same dilutions used for the physiological groups and the fungi which developed were identified to the genus. The results obtained for the different physiological groups are shown in Table 3, and the fungi found are listed in Table 4.

The low $\mathrm{pH}$ values of the nonvegetated samples of both the Canyon and Arthurdale spoil areas are reflected in the low MPN's of all bacteria determined, except the sulfur-oxidizers. The complete absence of nitrifiers and Azotobacter would be expected at such low $\mathrm{pH}$ values. 


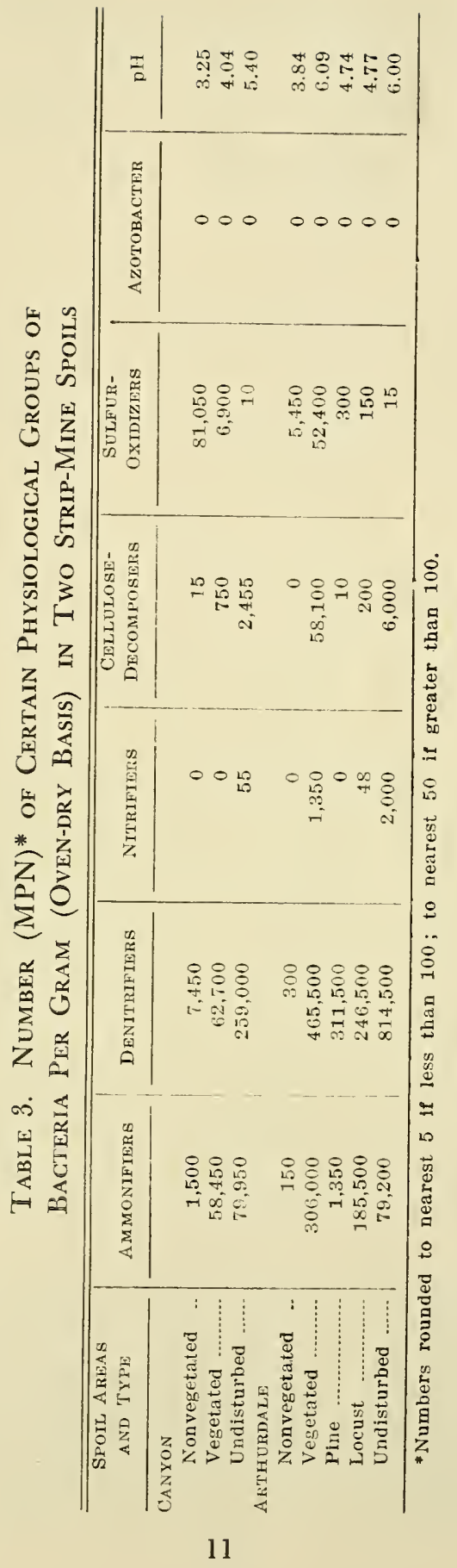




\section{Table 4. Genera of Fungi Found in Two Strip-Mine Spoil Areas $\dagger$}

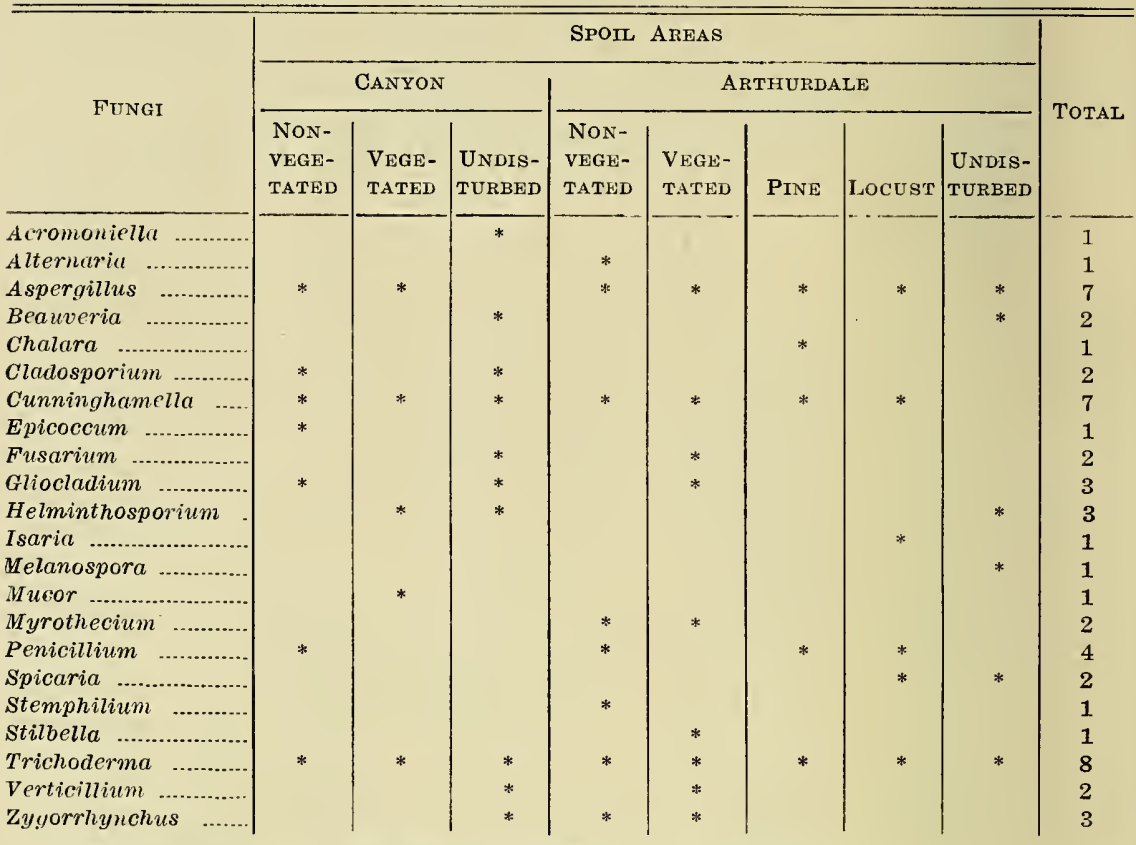

*Denotes presence: no marking denotes the fungus was not found.

$\dagger$ The authors wish to thank Dr. H. L. Barnett for the identification of the fungi.

Although the Canyon vegetated sample had a higher $\mathrm{pH}$ value than the nonvegetated one, it was nevertheless, strongly acid. The MPN of the various physiological groups of bacteria, however, were all somewhat greater in the vegetated sample than in the nonvegetated one, except for the nitrifiers, Azotobacter and the sulfur-oxidizers. Neither nitrifiers nor Azotobacter were found in the Canyon spoil. The MPN of the sulfuroxidizers in the vegetated sample of the Canyon spoil was extremely small as compared to the number in the nonvegetated sample. However, the reverse was true in the Arthurdale spoil. The explanation for this probably lies in the unequal distribution of the pyritic material in spoil, since the sulfur-oxidizers are apparently associated with such sulfurbearing materials.

Except for the number of denitrifiers and sulfur-oxidizers, the MPN of the physiological groups found in the pine sample was nearer to those found in the nonvegetated than any of the other samples. On the other hand, the locust spoil with a $\mathrm{pH}$ value the same as the pine spoil contained more ammonifiers, nitrifiers, and cellulose-decomposers than the pine spoil. The undisturbed soil of the Arthurdale area contained fewer cellulose-decomposers than the vegetated spoil, but more denitrifiers and nitrifiers. 
The fungi identified on the rose bengal agar belonged to 22 different genera (Table 4). The genus Trichoderma was found in all eight samples, and the genera Aspergillus and Cunninghamella in each of seven samples. All the other genera were found in four or fewer of the samples.

\section{Discussion}

Regardless of the $\mathrm{pH}$ of the spoil, if vegetation is present, the numbers of bacteria, fungi, and actinomycetes are usually greater than in an adjacent portion devoid of vegetation. These numerical differences are, in most cases, statistically significant. The addition of lime and fertilizer to the spoil, followed by seeding to forage grasses and legumes, has great influence upon the numbers of microorganisms after the vegetation has become established. This is true even though the spoil later gradually becomes medium to strongly acid.

The numbers of bacteria and fungi in spoil supporting growth of forage grasses and legumes exhibit a tendency to approach those of adjacent undisturbed soils. This is especially true of the 0-4-inch depth. This same tendency, however, is not reflected as strongly by the numbers of actinomycetes. It is known (13) that the majority of soil actinomycetes fail to grow below a pH of 4.8 to 5.0, although some will tolerate acid conditions of $\mathrm{pH} 3.0$ to 4.0. For example, the $\mathrm{pH}$ values of the Canyon and Pruntytown vegetated spoils are lower than their corresponding undisturbed soils and the numbers of actinomycetes are considerably less, but in the vegetated spoils of the Kaufmann and Arthurdale areas, the $\mathrm{pH}$ values and numbers of actinomycetes are greater or close to those of corresponding undisturbed soil.

Another similarity of the vegetated spoil to undisturbed soil, as far as numbers of organisms are concerned, is evident when the microbial densities at the two depths are compared. The general trend is for larger numbers of bacteria, fungi, and actinomycetes to the found in the 0-4-inch depth than in the 4-8-inch depth. In nonvegetated spoils at the Canyon and Kaufmann areas, however, the numbers of bacteria were greater in the 4-8-inch depth than at $0-4$ inches. Numbers at the two depths were equal in the Arthurdale area but smaller in the Pruntytown area. The difference, however, was usually not significant. A similar trend was exhibited by the actinomycetes, but the numbers of fungi were nearly equal in both depths, excepting at the Kaufmann area where the number in the 4-8-inch depth was much smaller. The reason for these differences is not entirely clear because of overlapping factors often present on the surface of nonvegetated spoil, such as high temperatures, dryness, and sunlight. Stiver (10) found in Indiana that the tem- 
perature at the surface of bare soil reached $124^{\circ} \mathrm{F}$. for a two-hour period during the day in midsummer, but at the 6-inch depth the maximum temperature was $103^{\circ} \mathrm{F}$.

The numbers of bacteria found in the spoil from the black locust planting were greater at both depths than those found in the adjacent pine-planted spoil. This difference is no doubt partially the result of better temperature conditions under the locust litter. A midday surface temperature of $123^{\circ} \mathrm{F}$. (June 21, 1944) was recorded by Chapman (3) on bare spoil in Ohio, but the temperature was only $85^{\circ} \mathrm{F}$. just beneath the litter in a locust planting. In general, the numbers of microorganisms have increased according to the amount of surface cover, either vegetative or litter, from a light to no cover on the nonvegetated to a heavy on the undisturbed soil.

The low $\mathrm{pH}$ values of most of the samples would likely prohibit the occurrence of Azotobacter. None was found. A test was made for this organism, because it has been found in approximately one-third of all samples collected in an Azotobacter survey (6) made in the northern portion of the State and has been found once before in a sample from undisturbed soil at the Arthurdale area.

It may be concluded that the numbers of bacteria, fungi, and actinomycetes in spoil that has been limed, fertilized, and seeded to forage grasses and legumes will finally approach, or even equal, the numbers found in adjacent undisturbed soil.

The numbers of ammonifiers, denitrifiers, nitrifiers, and cellulosedecomposers are greater in spoil with vegetation than in nonvegetated spoil. The numbers of sulfur-oxidizers fluctuate somewhat, but in general, decrease with an increase in vegetation on these soils. Their abundance, however, is more likely to be more closely associated with the presence of sulfur-bearing materials in the soil.

Although no nitrifiers were found in the nonvegetated spoil from either the Canyon or Arthurdale areas, it is believed that they are present in extremely small numbers. In a recent investigation on the ammonifying power of Canyon spoil (15), it was found that the nitrification process did take place in nonvegetated spoil, if $\mathrm{Ca}(\mathrm{OH})_{2}$ was added to neutralize the acidity of the spoil sample.

Inasmuch as fungi usually are more tolerant of acid conditions than either bacteria or actinomycetes, the isolation of 22 different genera is perhaps not surprising. Of these genera, nine were found in spoil but not in the soil, and three were found only in the soil. No doubt, a more detailed investigation of strip-mine spoil for fungi would result in more than 22 genera being found. However, these results indicate that spoils such as these, even though strongly acid, harbor numerous fungi. 


\section{References}

1. Allen, M. I. Hussain, "Counting of Azotobacter in Soils." Plant and Soil, Vol. 4 (1953), pp. 248-251.

2. Bryner, L. C., Beck, J. V., Davis, D. B., and Wilson, D. G., "Microorganisms in Leaching Sulfide Minerals." Industrial and Engineering Chemistry, Vol. 46 (1954), pp. 2587-2592.

3. Chapman, A. G., Forest Planting on Strip-Mined Coal Lands with Special Refercnce to Ohio. Central States Forest Experiment Station (USDA) Columbus 15, Ohio. Tech. Paper 104. 1944.

4. Colmer, A. R., and Hinkle, M. E., "The Role of Microorganisms in Acid Mine Drainage: A Preliminary Report." Science, Vol. 106 (1947), pp. 253-256.

5. Fred, E. B., and Waksman, S. A., Laboratory Manual of General Microbiology. New York, McGraw-Hill Book Company, Inc., 1928.

6. Hedrick, H. G., and W'ilson, H. A., Unpublished Data.

7. Hinkle, M. E., and Koehler, W. A., "The Action of Certain Nicroorganisms in Acid Mine Drainage." Amer. Inst. Mining and Metallurgical Engineers, Class $F$, Coal Technology, Tech. Pub. 2381. 1948.

8. Salle, A. J., Laboratory Manual on Fundamental Principles of Bacteriology, 3rd ed. New York, McGraw-Hill Book Company, Inc., 1948.

9. Smith, N. R., and Dawson, V. T., "The Bacteriostatic Action of Rose Bengal in Media Used for Plate Counts of Soil Fungi." Soil Sci. Vol. 58 (1944) pp. 467-471.

10. Stiver, Edward N., Revegetation of Strip Coal Spoil Banks of Indiana. (From a thesis, February 1949, Purdue University). Div. Forestry, Ind. Coal Prod. Association. Terra Haute, Indiana (1949).

11. Tyner, E. H., and Smith, R. M.," "The Reclamation of the Strip-Mined Coal Lands of West Virginia with Forage Species." Soil Sci. Amer. Proc. (1945) Vol. 10 (1946), pp. 429-436.

12. Tyner, E. H., Smith, R. M., and Galpin, S. L., "Reclamation of Strip-Mined Areas of West Virginia." Jour. Amer. Soc. A gron. Vol. 40 (1948), pp. 313-323.

13. Waksman, S. A., Principles of Soil Microbiology. Baltimore, The Williams and Wilkins Company, 1927.

14. West Virginia, State of: Strip Mining Rules and Regulations, Dept. of Mines, Charleston, West Virginia, (1946).

15. Wilson, H. A., and Stewart, Gwendolyn, Ammonification and Nitrification in $a$ Strip Mine Spoil. W. Va. Univ, Agr. Expt. Sta. Bull. 379T, 1955. 


